UDC 622.276.1/.4(4/9)

\title{
A NEW INFLOW PERFORMANCE RELATIONSHIP \\ FOR YEMEN OIL FIELDS
}

НОВЫЙ ВИД ИНДИКАТОРНОЙ ДИАГРАММЫ

ДЛЯ НЕФТЯНЫХ МЕСТОРОЖДЕНИЙ ЙЕМЕНА

\begin{abstract}
Abbas Mohamed Al-Khudafi, Salem Mubarak Bin-Gadeem, Khaled Saeed Ba-Jaalah
\end{abstract}

Hadhramout University, Al-Mukalla, Yemen

Abdulla Ali Aldambi, Aden University, Aden, Yemen

Аббас Мохамед Аль-Худафи, Салим Мубарак Бын-Гадем, Халид Саид Ба-Яалах

Хадхрамутский университет, г. Аль-Мукалла, Йемен Абдулла Али Алдамби

Аденский университет, г. Аден, Йемен e-mail: prof.abuahmad@yahoo.com

\begin{abstract}
Predicting the relationship between the flow rate and the pressure drop performance in the reservoir is very important for continuous production optimization in the field. The inflow performance relationship (IPR) describes the relationship between the flow rate of the well (q) and the following pressure of that well $\left(\mathrm{P}_{\mathrm{wf}}\right)$. Different inflow performance relationship correlations exist today in the petroleum industry with the most commonly used models are that of Vogel, Wiggins, Klins and Majher, Fetkovich and Sukarno and Wisnogroho. The goal of this work is to develop a new model to predict the inflow
\end{abstract}


performance relationship curve for Yemeni oil reservoirs. This new correlation was developed using about 3470 data points were collected from different Yemen oil reservoirs. Initially, common correlations considered in this study were evaluated for the Yemeni oil reservoirs data. To improve the performance of these correlations their coefficients were regenerated to fit the Yemeni oil reservoir samples data set using linear and nonlinear regression methods. The behavior of new developed models was evaluated using statistical error analysis. The new developed models show accuracy with the desirable engineering limits.

Аннотация. Разработана новая модель индикаторной кривой для условий нефтяных месторождений Йемена. Тестирование новой модели было произведено путем сравнения ее точности с наиболее распространенными методиками: Фогеля, Фетковича, Клинса-Маджера, Виггинса и Сукарно-Висногрохо. Эта новая модель была разработана с использованием около 3470 параметров, полученных из различных нефтяных месторождений в Йемене. Первоначально методы, рассмотренные в этой работе, были оценены с учетом специфики йеменских нефтяных пластов. Для повышения точности этих методик коэффициенты были скорректированы в соответствии с параметрами проб йеменских нефтяных пластов с использованием методов линейной и нелинейной регрессии. Фактические данные и данные, полученные из новой модели, Фогеля, Фетковича, Клинса-Маджера, Виггинса, СукарноВисногрохо, сравниваются с использованием статистического и графического анализа точности. Индикаторные кривые для йеменских нефтяных месторождений были получены с использованием тех же процедур, которые предложены Фогелем для нефтяных залежей в условиях режима растворенного газа. Параметры новой модели определяются с использованием процедуры нелинейной оптимизации, в частности модулей Solver, реализованных в Microsoft Excel. Проверка и тестирование новой модели были произведены путем сравнения ее точности с наиболее распространенными методиками: Фогеля, Фетковича, Уиггинса и Сукарно. 
Для сравнения используются средние процентные абсолютные погрешности между фактическими данными расхода и вычисленными данными расхода новой модели, предложенной в этой работе. Показано, что новая разработанная модель характеризуется самой низкой средней абсолютной процентной погрешностью: 8,81 \%, в то время как модель Фетковича имеет среднюю абсолютную погрешность, равную 11,61%. Модели Виггинса, Фогеля, Сукарно-Висногрохо, Клинса-Маджера имеют средние абсолютные погрешности, составляющие 13,58 \%, 19,50 \%, 25,85 $\%$ и 49,14 \% соответственно. Новые разработанные модели обеспечивают построение индикаторной диаграммы в условиях специфики нефтяных скважин на йеменских нефтяных месторождениях $\mathrm{c}$ желательной точностью для технических целей без необходимости исследования скважин на притоке, которые считаются более дорогостоящими и трудоемкими.

Key words: inflow performance Relationship, new model, Yemeni oil reservoirs, empirical correlations

Ключевые слова: новая модель, нефтяные месторождения Йемена, индикаторная диаграмма

\section{Introduction}

The IPR is often required for designing well completion, optimizing well production, nodal analysis calculations, and designing artificial lift. If the wellbore pressure is equal to the reservoir pressure, there can be no inflow. If the wellbore pressure is zero, the inflow would be the maximum possible Absolute Open Flow (AOF). For intermediate wellbore pressures the inflow will vary. For each reservoir, there will be a unique relationship between the inflow rate and wellbore pressure. In single phase flow, the inflow performance curve is a 
straight line, but when gas is moving in the reservoir, at a pressure below the bubble point, this is not a linear relationship as shown in Figure 1.

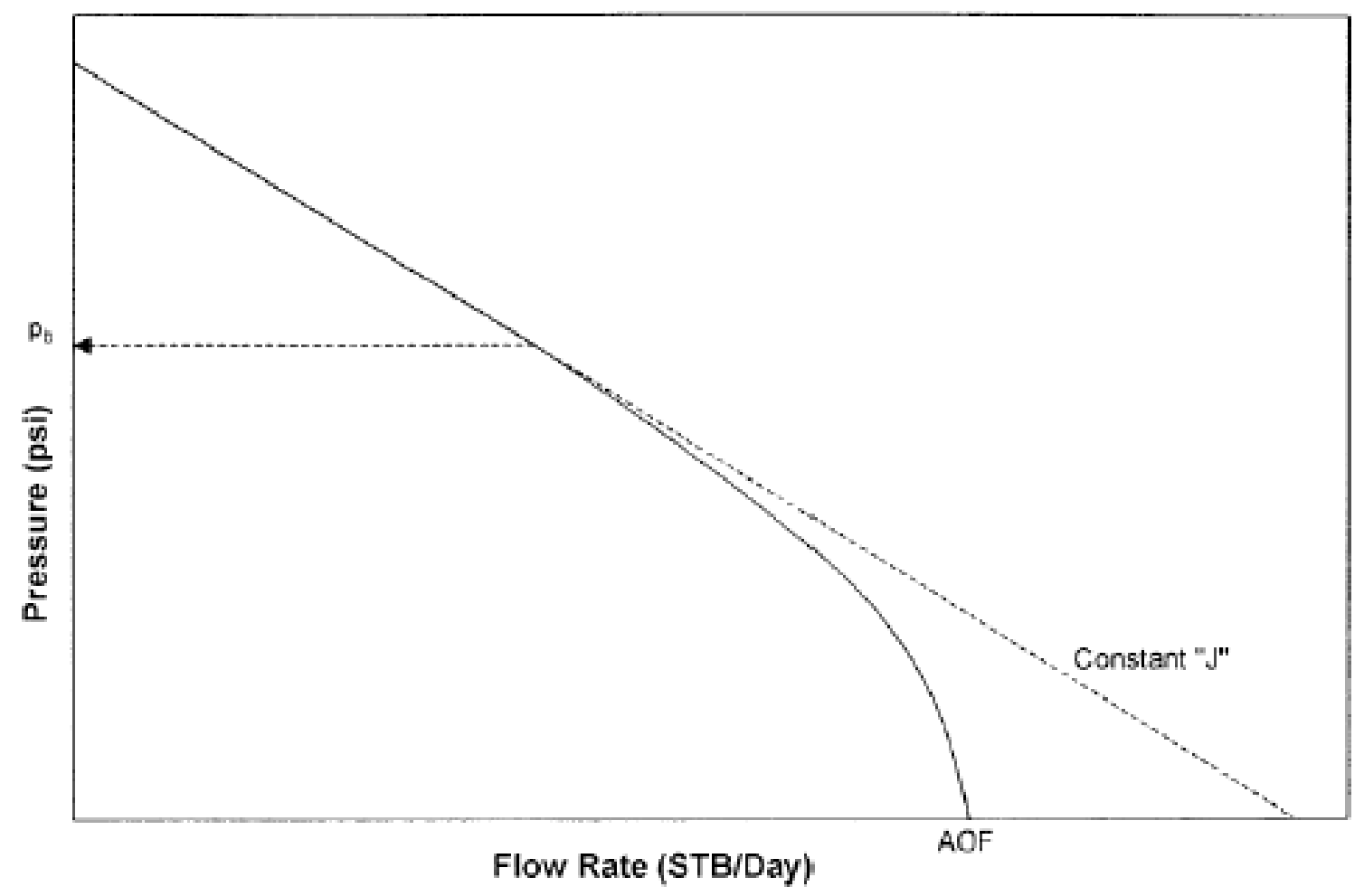

Figure 1. The inflow performance curve

Many IPR correlations addressed the curvature in Figure (1) of the inflow performance curves in case of solution gas drive oil reservoirs in which the babble point pressure is the initial reservoir pressure.

Vogel (1968) [1] developed an empirical relationship for inflow performance relationship (IPR) correlation by using a computer program based on Weller's assumptions and twenty-one reservoir data sets to develop an inflow performance relationship correlation as:

$$
\frac{q_{o}}{q_{\text {omax }}}=1-0.2\left[\frac{P_{w f}}{P_{r}}\right]-0.8\left[\frac{P_{w f}}{P_{r}}\right]^{2} .
$$

Figure 2 presented the Vogel plot illustrating the liquid (oil), gas (dry gas), and solution gas-drive cases. Vogel's correlation gave a good match with the actual well inflow performance at early stages of production, but deviates at later stages of the reservoir life. Vogel correlation didn't include IPR curves for wells with damage or high viscosity. 


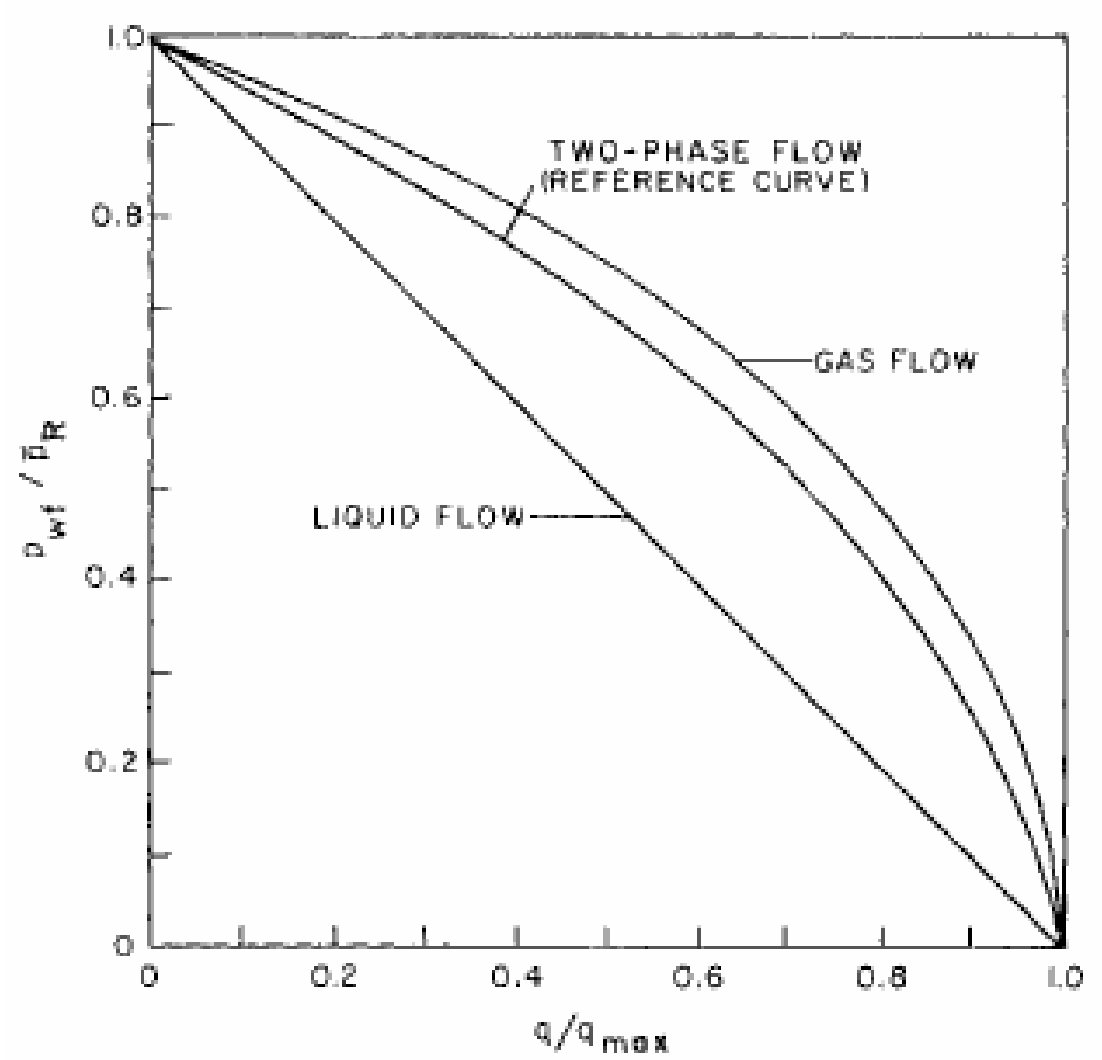

Figure 2. IPR schematic plot for single phase oil, single phase gas and solution gas drive system [1]

Fetkovitch (1973) [2] developed an empirical equation based on two correlation parameters, maximum oil flow rate and deliverability exponent for Fetkovich. He proposed a method for calculating the inflow performance for oil wells using the same type of equation that has been used for analyzing gas wells for many years. This empirical equation is given in the following form:

$$
\frac{q_{o}}{q_{\text {omax }}}=\left[1-\left(\frac{P_{w f}}{P_{r}}\right)^{2}\right]^{n}
$$

Figure 3 is a rationale for the preference of the above equation. To apply the above correlation, well measurements must be performed during at least two stable flow conditions to determine the value of deliverability exponent. 


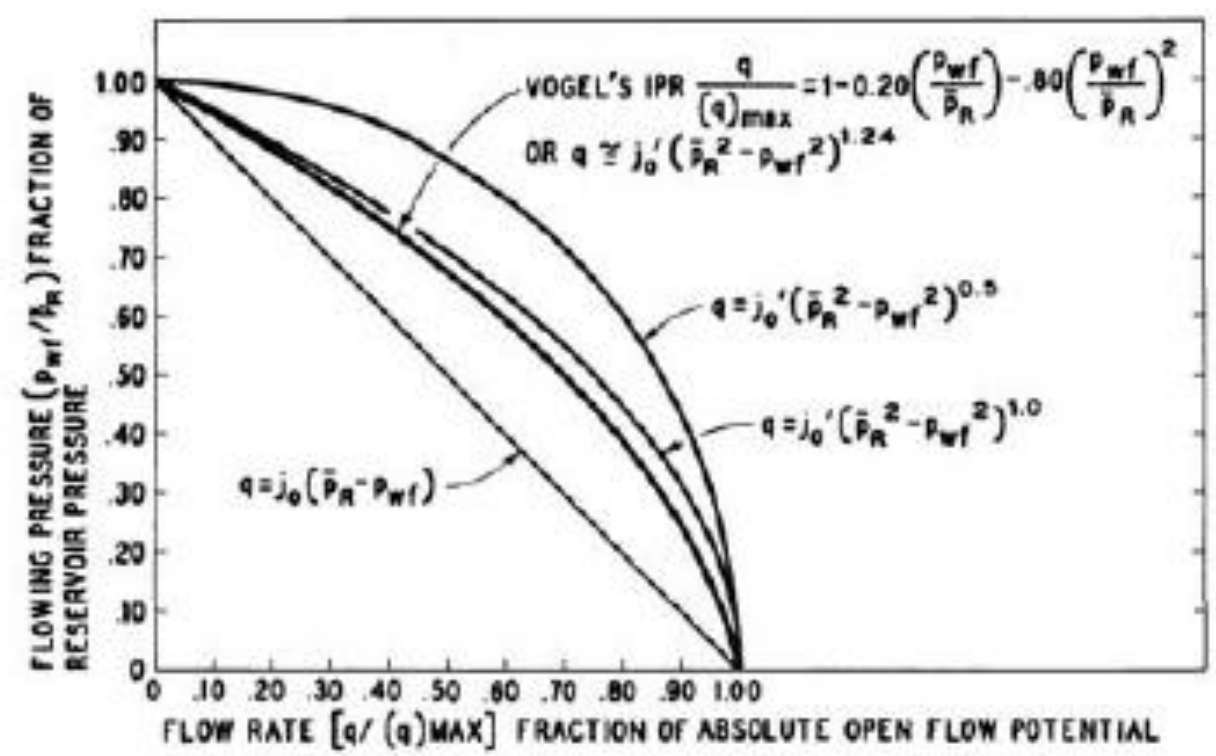

Figure 3. IPR for various flow equations [2]

Klins and Majher (1992) [3] developed an inflow performance relationship correlation that takes into account the change in bubble-point pressure and reservoir pressure based on Vogel's work. They used the same twenty-one solution gas drive reservoirs that previously used by Vogel. This correlation is given by the following

$$
\frac{\mathrm{q}_{\mathrm{o}}}{\mathrm{q}_{\mathrm{omax}}}=1-0.295\left[\frac{\mathrm{P}_{\mathrm{wf}}}{\mathrm{P}_{\mathrm{r}}}\right]-0.705\left[\frac{\mathrm{P}_{\mathrm{wf}}}{\mathrm{P}_{\mathrm{r}}}\right]^{\mathrm{N}},
$$

where

$$
\mathrm{N}=\left(0.28+0.72 \frac{\mathrm{P}_{\mathrm{r}}}{\mathrm{P}_{\mathrm{b}}}\right)\left(1.235+0.001 \mathrm{P}_{\mathrm{b}}\right) .
$$

Wiggins (1993) [4] developed the following generalized empirical three phase IPR similar to Vogel's correlation based on his developed analytical model in 1991:

$$
\frac{q_{o}}{q_{\text {omax }}}=1-0.519167\left[\frac{P_{w f}}{P_{r}}\right]-0.481092\left[\frac{P_{w f}}{P_{r}}\right]^{2} .
$$

Wiggins, et al. (1991, 1992) found that the main reservoir parameter that plays a major role in the inflow performance curve is the oil mobility function. The major problem in applying this IPR is its requirement for the mobility 
derivatives as a function of reservoir pressure, which is very difficult in practice. Therefore, in 1993 Wiggins developed an empirical IPR correlation from this analytical IPR model by assuming a third degree polynomial relationship between the oil mobility function and reservoir pressure. Wiggins, et al. also presented plots of the oil mobility as a function of reservoir pressure taken at various flow rates.

Sukarno and Wisnogroho (1995) [5] developed an IPR correlation based on simulation results that attempts to account for the flow efficiency variation caused by rate-dependent skin. This equation is given in the following form:

$$
\frac{q_{o}}{q_{\text {omax }}}=F E\left[1-0.1489 \frac{P_{w f}}{P_{r}}-0.4416\left(\frac{P_{w f}}{P_{r}}\right)^{2}-0.4093\left(\frac{P_{w f}}{P_{r}}\right)^{3}\right],
$$

where

$$
F E=a_{0}+a_{1} \frac{P_{w f}}{P_{r}}+a_{2}\left(\frac{P_{w f}}{P_{r}}\right)^{2}+a_{3}\left(\frac{P_{w f}}{P_{r}}\right)^{3}
$$

and

$$
a_{i}=b_{o i}+b_{1 i} \times s+b_{2 i} \times s^{2}+b_{3 i} \times s^{3} .
$$

In the above equation $\mathrm{s}$ is the skin factor and $b_{o i}, b_{1 i}$ and $b_{2 i}$ are the fitting coefficients that are shown in Table 1.

Table 1. Constants for Sukarno and Wisnogroho Correlation

\begin{tabular}{|c|c|c|c|c|}
\hline & $b_{0 i}$ & $b_{1 i}$ & $b_{2 i}$ & $b_{3 i}$ \\
\hline $\mathrm{a}_{0}$ & 1.0394 & 0.12567 & 0.0135 & -0.00062 \\
\hline $\mathrm{a}_{1}$ & 0.01668 & -0.00385 & 0.00217 & -0.0001 \\
\hline $\mathrm{a}_{2}$ & -0.0858 & 0.00201 & -0.00456 & 0.0002 \\
\hline $\mathrm{a}_{3}$ & 0.00952 & -0.00391 & 0.0019 & -0.00001 \\
\hline
\end{tabular}

\section{Data acquisition for modelling}

About 3470 data points were collected from west, north, east and south of Yemeni oil fields which are being used in this study to evaluate the inflow 
performance relationship models and for developing the new model. The data ranges and description of these data are shown in Table 2.

Table 2. Range of parameters

\begin{tabular}{|l|c|c|c|}
\hline \multicolumn{1}{|c|}{ Parameter } & Maximum & Minimum & Average \\
\hline $\mathrm{P}_{\mathrm{r}, \mathrm{psia}}$ & 4164.5 & 366 & 1654.9 \\
\hline $\mathrm{p}_{\mathrm{wf}}$ test, $\mathrm{psia}$ & 3263 & 71 & 749.8 \\
\hline $\mathrm{q}_{\mathrm{o}}$ test, STB/D & 3444 & 116 & 583.7 \\
\hline $\mathrm{q}_{\mathrm{o}} \mathrm{max}, \mathrm{STB} / \mathrm{D}$ & 29196.6 & 210.8 & 1708.2 \\
\hline $\mathrm{p}_{\mathrm{wf}}, \mathrm{psia}$ & 4164.5 & 0 & 821 \\
\hline $\mathrm{J}, \mathrm{STB} / \mathrm{D} / \mathrm{psi}$ & 10.4 & 0.05 & 1.1 \\
\hline $\mathrm{p}_{\mathrm{b}}, \mathrm{psia}$ & 3450 & 34 & 520.5 \\
\hline
\end{tabular}

\section{Developed new model}

The objective of this work is to develop a simple and consistent method to correlate IPR trends for Yemen oil reservoir systems without direct knowledge of the distributions of gas oil ratio and the saturation profiles. The IPR curves for Yemen oil reservoirs were generated using the same procedure that Vogel proposed for solution gas-drive reservoirs. The parameters of new model are determined using a non-linear optimization routine, specifically the «Solver» modules implemented in Microsoft Excel. The new model was written as

$$
\frac{q_{o}}{q_{\text {omax }}}=1.2359322-1.25646325\left[\frac{P_{w f}}{P_{r}}\right]+0.0232948\left[\frac{P_{w f}}{P_{r}}\right]^{2} .
$$

The actual data and the data results from new model, Vogel, Fetkovich, Klins and Majher, Wiggins and Sukarno and Wisnogroho models are plotted together in Figures 4-9. Figure 4 shows that the crossplot of data results from new developed model almost fall on the $45^{\circ}$ line implying excellent correlation. The crossplot of Vogel, Fetkovech and Wiggins models above the $45^{\circ}$ line while the crossplot of Klins and Majher and Sukarno and Wisnogroho models below the $45^{\circ}$ line as shown in Figures 5-9. 


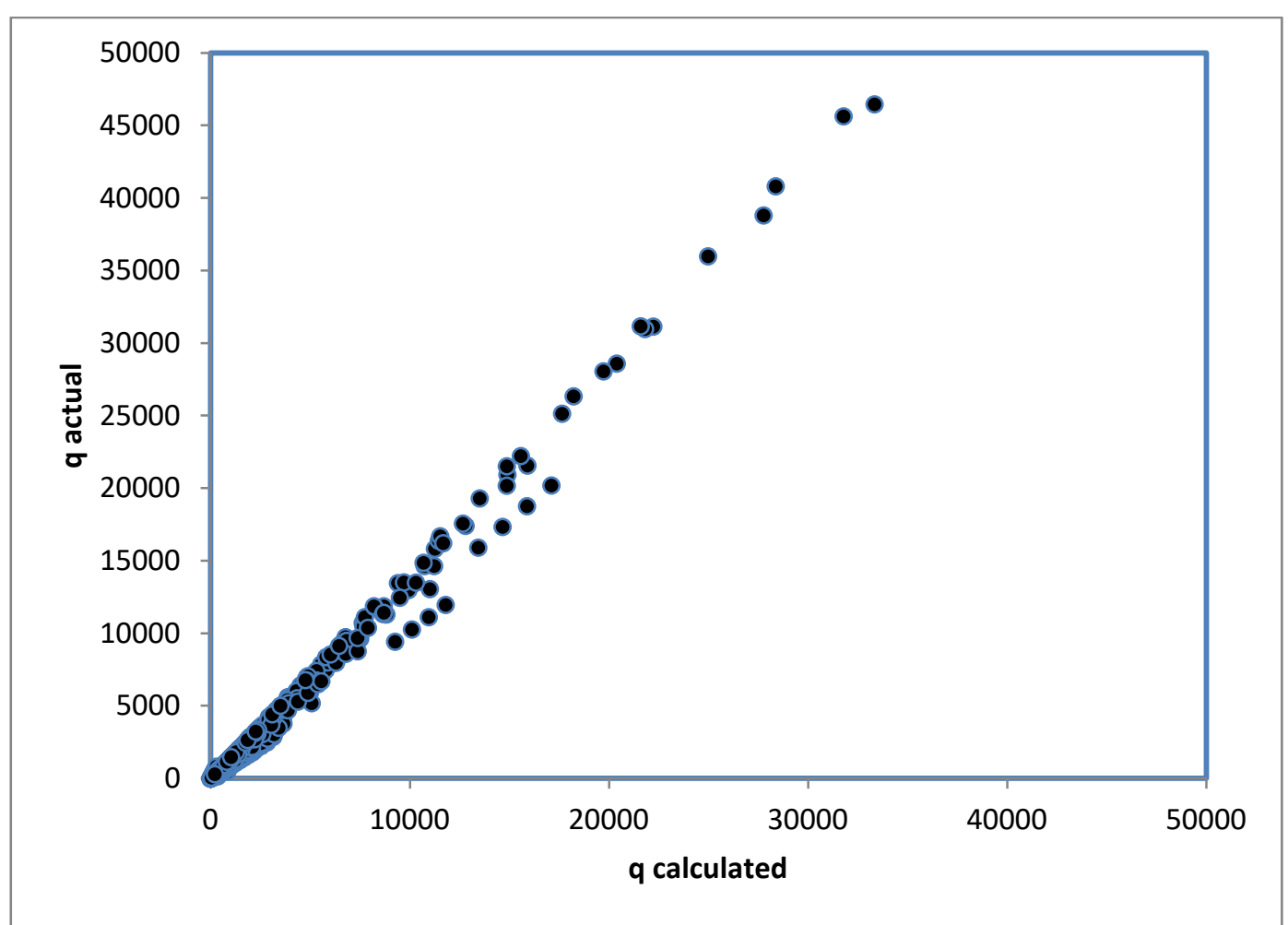

Figure 4. Crossplot of actual data against predicted data from new model

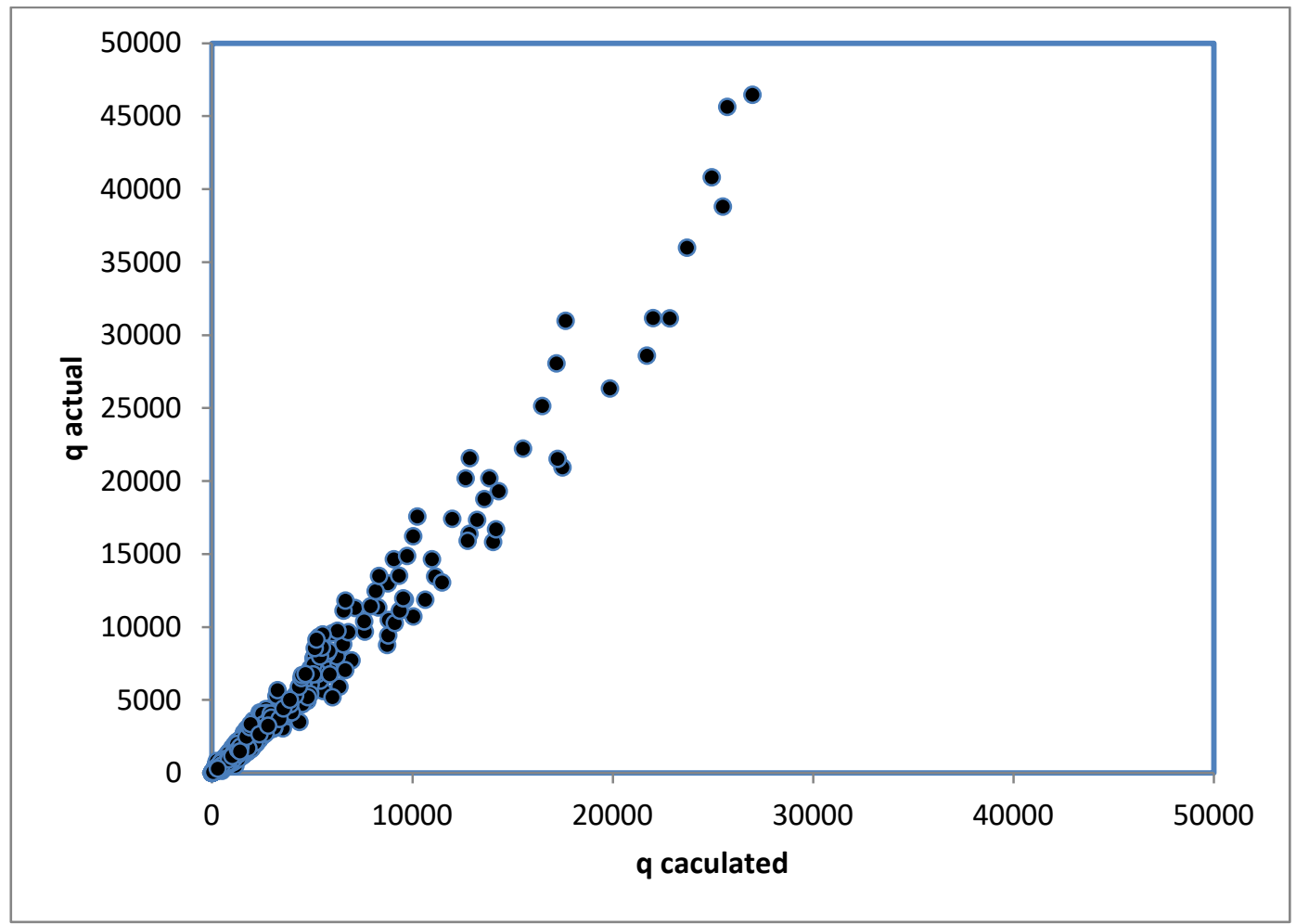

Figure 5. Crossplot of actual data against predicted data from Vogel model 


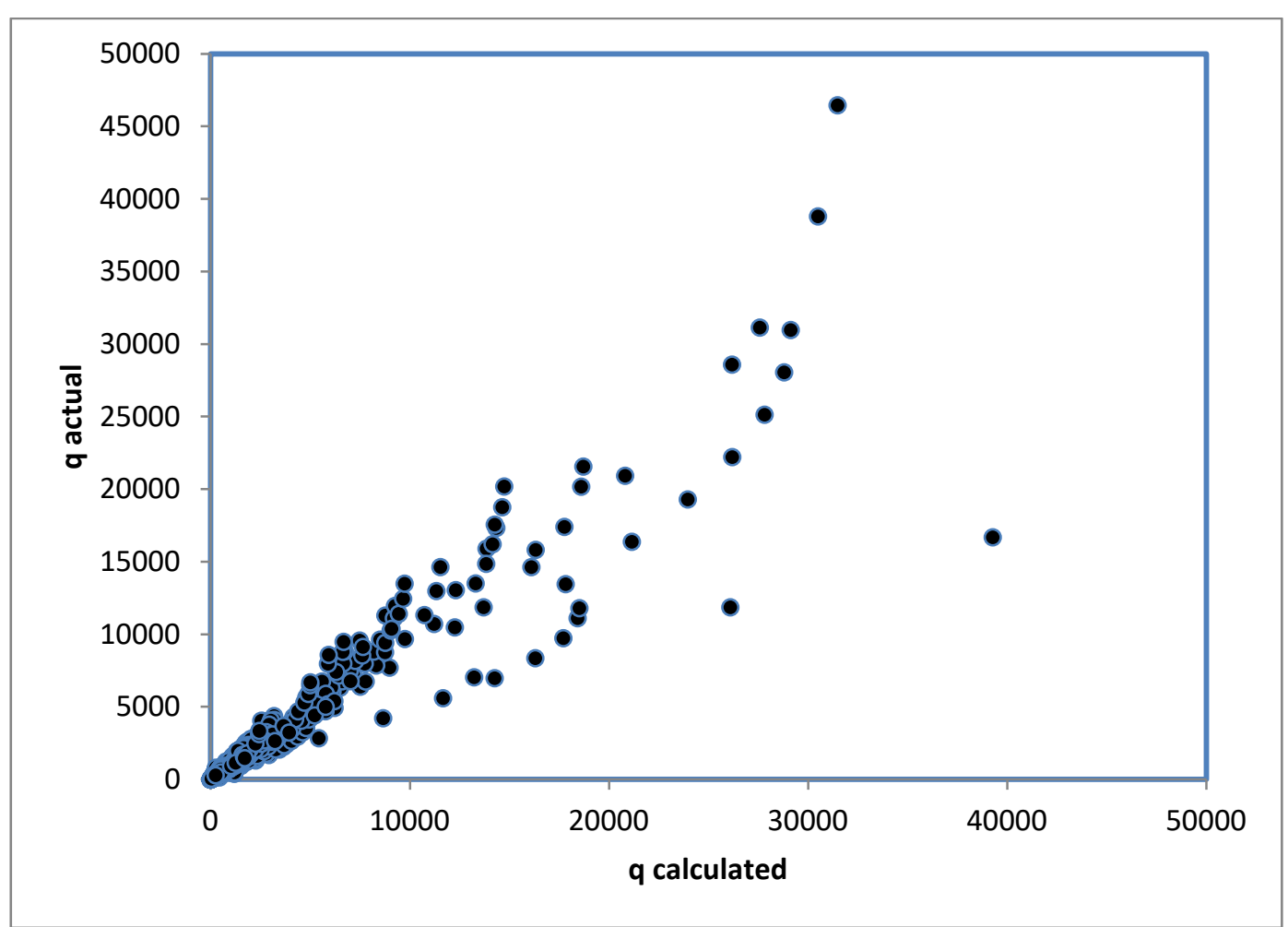

Figure 6. Crossplot of actual data against predicted data from Fetkovich model

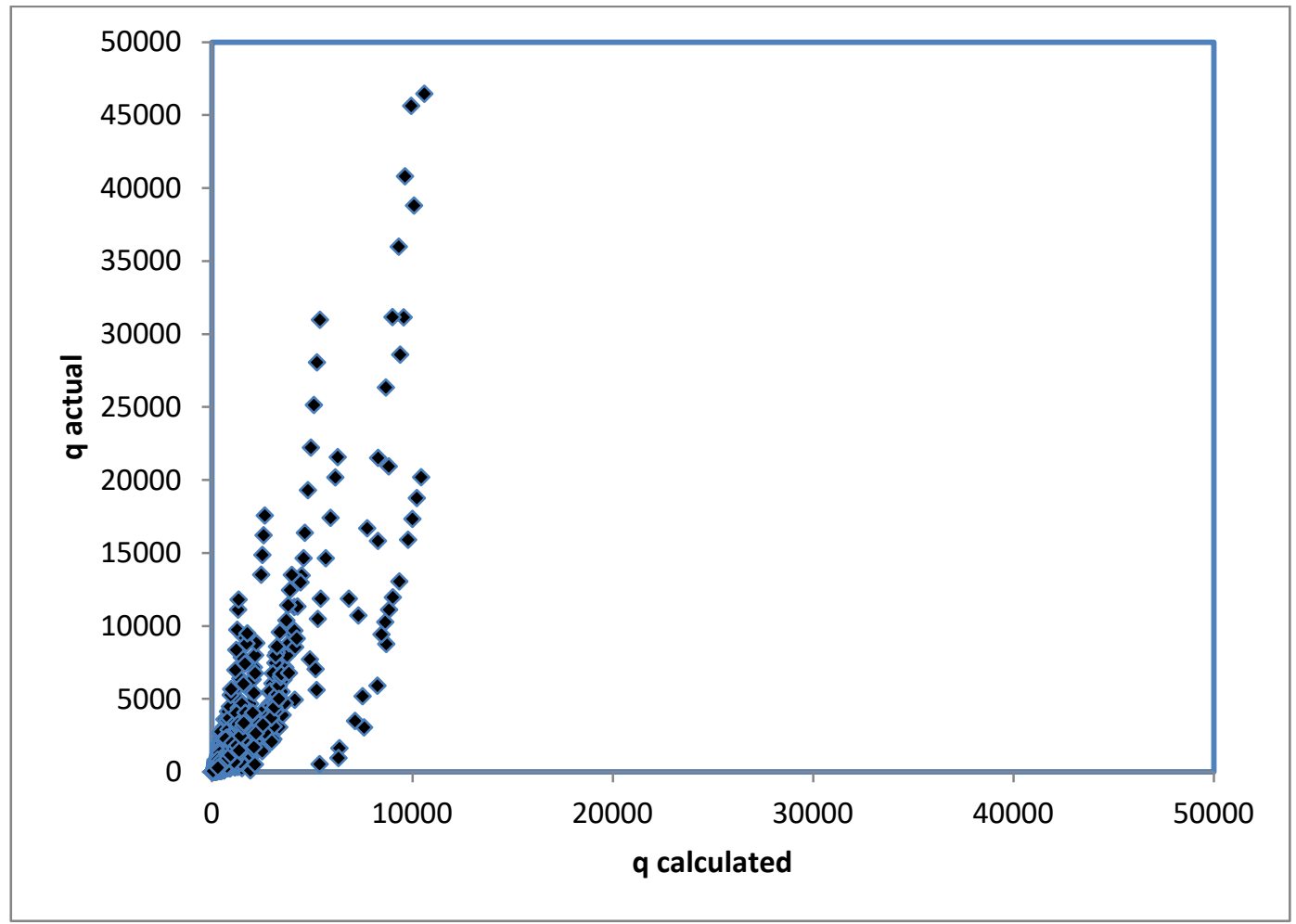

Figure 7. Crossplot of actual data against predicted data from Klins and Majher model 


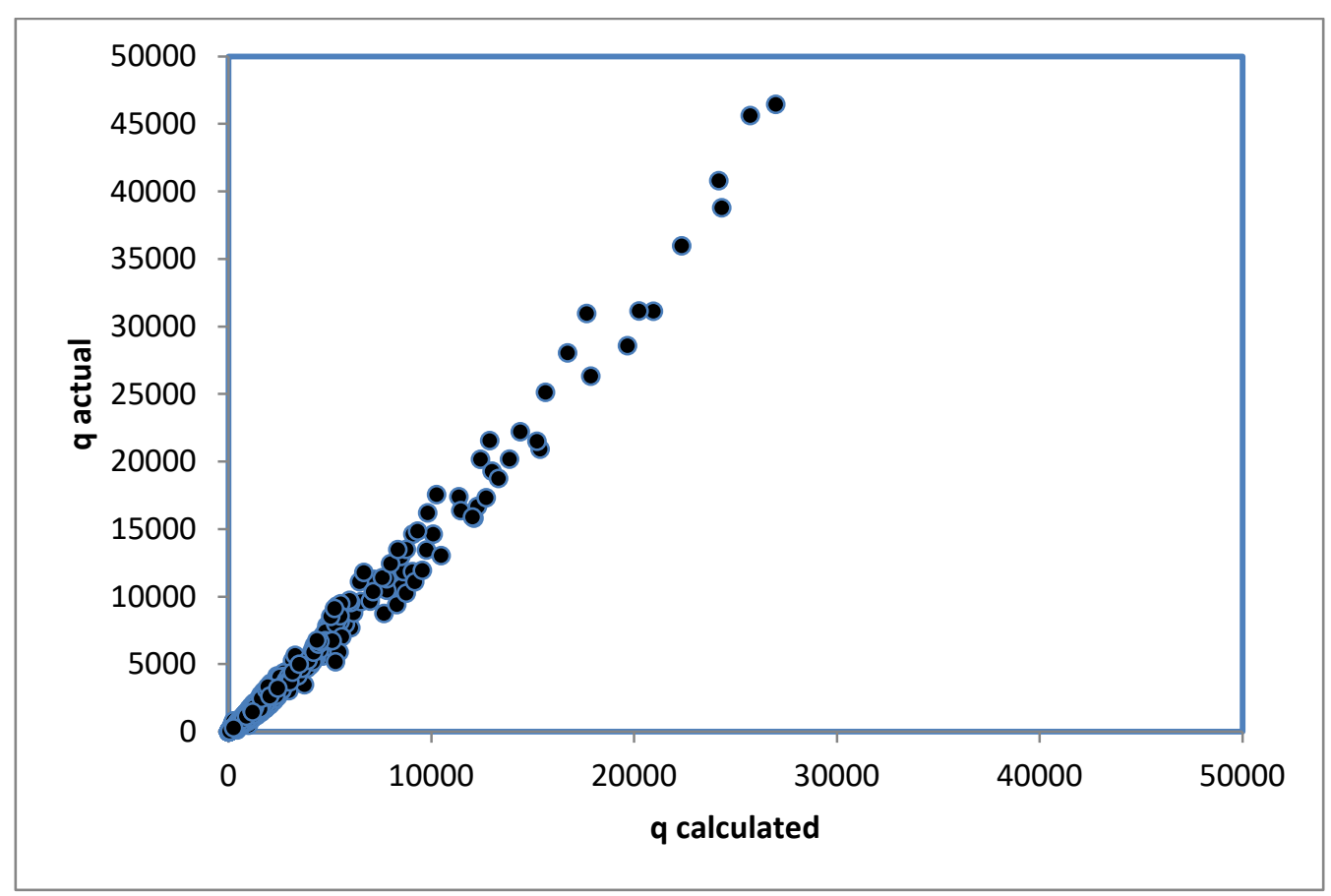

Figure 8. Crossplot of actual data against predicted data from Wiggins model

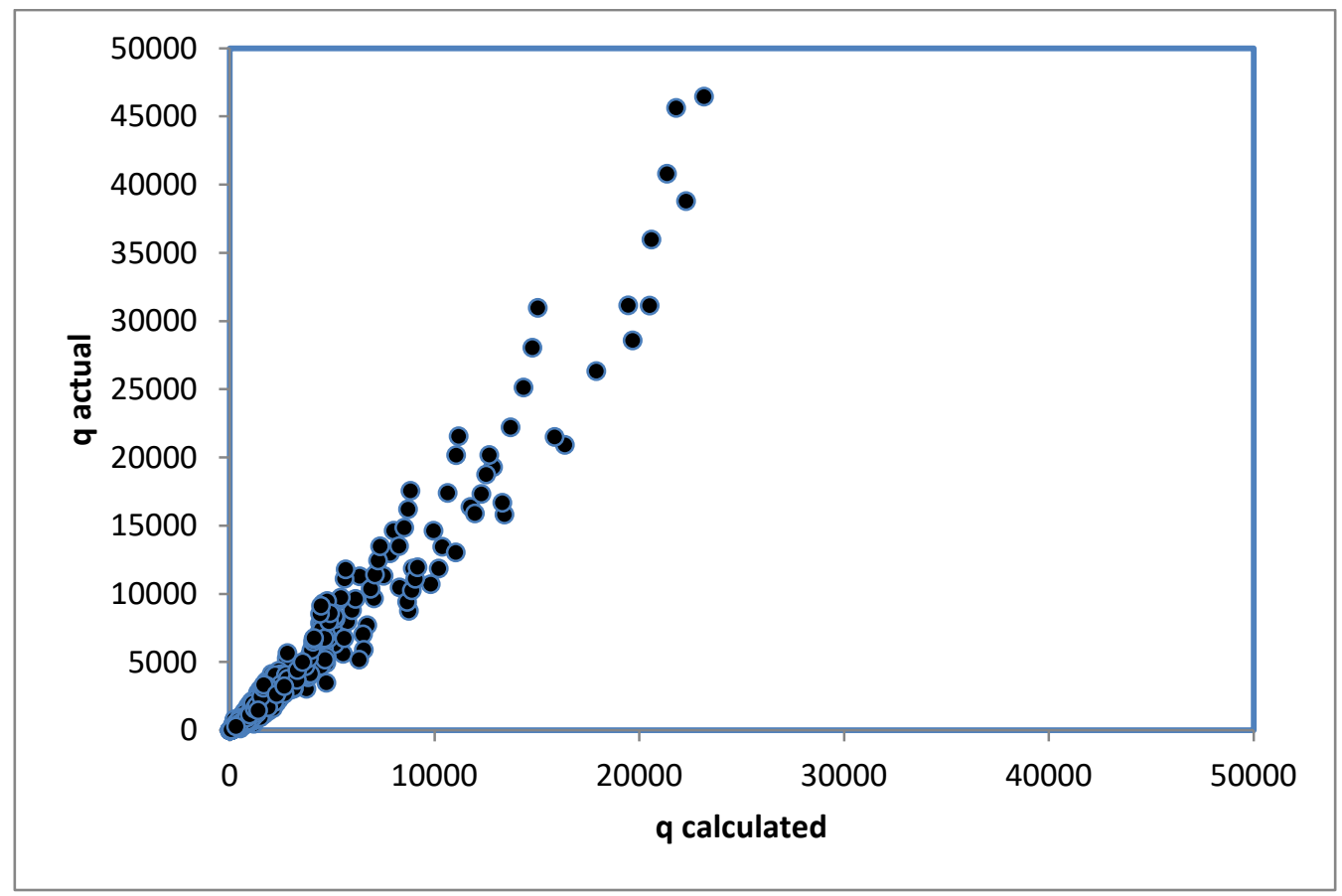

Figure 9. Crossplot of actual data against predicted data from Sukarno and Wisnogroho model

\section{Validation of the new inflow performance relationship (IPR) model}

To verify and validate the new developed IPR model, the new model was tested by comparing its accuracy with that of the most common IPR models 
such as Vogel, Fetkovich, Klins and Majher, Wiggins and Sukarno and Wisnogroho models [6].

The average absolute errors percent between the actual flow rate data and the calculated rate for the IPR methods that used in this study and new model are shown in Figure 10 for the comparison. It is clear from this Figure that the new developed IPR model has the lowest average absolute error percent that is $8.805 \%$, while the average absolute error percent for Fetkovich method is $11.606 \%$. The other methods have average absolute errors percent ranging of $13.576 \%, 19.499 \%, 25.847 \%$ and $49.139 \%$ for Wiggins, Vogel, Sukarno and Wisnogroho and Klins and Majher, respectively.

Table 3 presents a summary of the average absolute errors percent that was obtained for each method. As indicated, the method of the new developed IPR model always provided the lowest value of the total average absolute error percent in comparison with that of other models.

Table 3. Summary of the average absolute error present

\begin{tabular}{|c|c|c|c|c|c|c|}
\hline Model & Vogel & $\begin{array}{c}\text { Klins and } \\
\text { Majher }\end{array}$ & $\begin{array}{c}\text { Sukarno and } \\
\text { Wisnogroho }\end{array}$ & Wiggin & Fetkovich & New Model \\
\hline $\begin{array}{c}\text { Average } \\
\text { Error \% }\end{array}$ & 19.499 & 49.139 & 25.847 & 13.576 & 11.606 & 8.805 \\
\hline
\end{tabular}

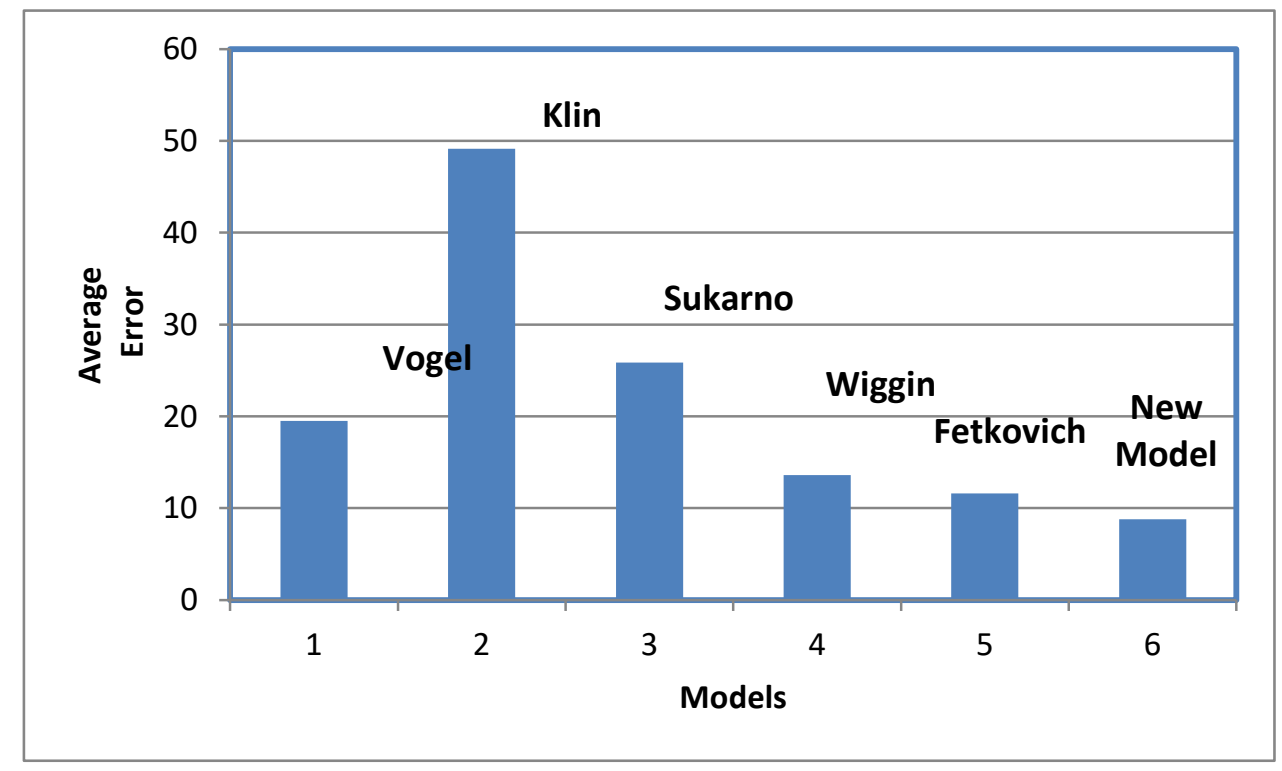

Figure 10. The average absolute error analysis 


\section{Conclusions}

1. The new IPR model was developed to construct and predict the IPR curve for Yemen reservoirs.

2. The validity of the new IPR model was tested in comparison with the behavior of the most common methods that are used in the industry. The results of this validation showed that the new IPR model ranked the first model that succeeded to predict the behavior of the IPR curve while the other models of Fetkovich, Wiggins, Vogel, Sukarno and Wisnogroho and Klins and Majher ranked the second, the third, the forth, the fifth and the sixth respectively.

3. The new IPR model requires one test point to estimate the maximum flow rate.

\section{Nomenclatures}

$n=$ Deliverability exponent for Fetkovich, dimensionless

$P_{b}=$ Bubble Point Pressure, psia

$P_{r}=$ Average reservoir pressure, $\mathrm{psia}$

$P_{w f}=$ Bottom hole flowing pressure, psia

$q_{o}=$ Oil flow rate, $\mathrm{STB} / \mathrm{D}$

$q_{\text {omx }}=$ Maximum oil flow rate, $\mathrm{STB} / \mathrm{D}$

\section{References}

1. Ahmed Tarek. Advanced Reservoir Engineering. Elsevier Inc,. Gulf Professional Publishing, 2005.

2. Fetkovich M.J. The Isochronal Testing of Oil Wells. SPE Paper 4529 Presented at the Fall Meeting of the Society of Petroleum Engineers of AIME, Las Vegas, NV, 1973.

3. Klins M.A., Majher M.W. Inflow Performance Relationships for Damaged or Improved Wells Producing under Solution-Gas Drive. SPE paper 19852, Journal of Petroleum Technology, 1992, Vol. 44, No. 12, pp. 1357-1363. 
4. Sukarno P., Wisnogroho A. Generalized Two-Phase IPR Curve Equation under Influence of Non-Linear Flow Efficiency. Proc. Soc of Indonesian Petroleum Engineers Production Optimization Intl. Symposium, Indonesia, Bandung, 1995. pp. 31-3.

5. Vogel J.V. Inflow Performance Relationships for Solution Gas Drive Well. Journal of Petroleum Technology, 1968, Vol. 20, No. 1, pp. 83-92. DOI: 10.2118/1476-PA.

6. Wiggins M.L. Generalized Inflow Performance Relationships for ThreePhase Flow. SPE Paper 25458 Presented at the SPE Production Operations Symposium, Oklaho.

\section{Список используемых источников}

1. Ahmed Tarek. Advanced Reservoir Engineering. Elsevier Inc,. Gulf Professional Publishing, 2005.

2. Fetkovich M.J. The Isochronal Testing of Oil Wells // SPE Paper 4529 Presented at the Fall Meeting of the Society of Petroleum Engineers of AIME, Las Vegas, NV, 1973.

3. Klins M.A., Majher M.W. Inflow Performance Relationships for Damaged or Improved Wells Producing under Solution-Gas Drive // SPE Paper 19852, Journal of Petroleum Technology. 1992. Vol. 44. No. 12. pp. 1357-1363.

4. Sukarno P., Wisnogroho A. Generalized Two-Phase IPR Curve Equation under Influence of Non-Linear Flow Efficiency // Proc., Soc of Indonesian Petroleum Engineers Production Optimization Intl. Symposium, Indonesia, Bandung, 1995. pp. 31-3.

5. Vogel J.V. Inflow Performance Relationships for Solution Gas Drive Well // Journal of Petroleum Technology. 1968. Vol. 20. No. 1. pp. 83-92. DOI: 10.2118/1476-PA.

6. Wiggins M.L. Generalized Inflow Performance Relationships for ThreePhase Flow // SPE Paper 25458 presented at the SPE Production Operations Symposium, Oklahoma City, 1993. DOI: 10.2118/25458-MS. 


\section{About the authors}

\section{Об авторах}

Abbas Mohamed Al-Khudafi, Department of Petroleum Engineering, Hadhramout University, Al-Mukalla, Yemen

Аббас Мохамед Аль-Худафи, отдел нефтегазового дела, Хадхрамутский университет, Аль-Мукалла, Йемен

e-mail: prof.abuahmad@yahoo.com

Salem Mubarak Bin-Gadeem, Department of Petroleum Engineering, Hadhramout University, Al-Mukalla, Yemen

Салим Мубарак Бын-Гадем, отдел нефтегазового дела, Хадхрамутский университет, Аль-Мукалла, Йемен

Khaled Saeed Ba-Jaalah, Department of Petroleum Engineering, Hadhramout University, Al-Mukalla, Yemen

Халид Саид Ба-Яалах, отдел нефтегазового дела, Хадхрамутский университет, Аль-Мукалла, Йемен

Abdulla Ali Aldambi, Faculty of Science, Aden University, Aden, Yemen

Абдулла Али Алдамби, Аденский университет, Факультет Науки, Аден, Йемен

e-mail: ALDAMB169@gmail.com 